International Review of Social History 46 (200I), pp. I 55-1 84

(C) 200 I Internationaal Instituut voor Sociale Geschiedenis

\title{
Class, Caste, and Gender among Cashew Workers in the South Indian State of Kerala 1930-2000*
}

\author{
A NNA LINDBERG
}

SUMmaRY: The main concern of this paper is the issue of women workers' identity and class consciousness. This investigation is principally based on in-depth interviews with three generations of female factory workers. Extremely unequal power relations between capital and labour is insufficient to explain the more pronounced exploitation of female workers over males. In spite of these women having the potential for collective power, their factory lives have been characterized by treatment in constant violation of labour laws. Low-caste female workers have gone through a process of effeminization which has acted to curb their class identity and limit their scope of action. In the process of caste and class emancipation, the question of gender has been neglected by trade union leaders and politicians. The radicalism of males is built upon women's maintaining of the families - a reality which strongly contradicts hegemonic gender discourses and confuses gender identities.

\section{INTRODUCTION}

I don't know when I was born, but it was in the time of the Travancore king. One day my mother took my brother, my sisters, and me to the cashew nut factory. I think I was seven years old. Since then I have been shelling in the cashew nut factory and I beat the cashew nuts with my shelling stick from morning to night. Those of my sisters who are still alive work there, too. My daughter is a sheller

\footnotetext{
* A version of this paper was originally delivered at the Third European Social Science History Conference in Amsterdam, April 2000. I wish to thank those present for their comments, particularly Lisa Lindsay. My sincere thanks also to Monica Erwér, Diana Mulinari, Lars Olsson, and Eva Österberg for valuable comments on an earlier version of this paper. I would also like to express my gratitude to the three anonymous referees for their relevant criticism of the previous version. I am most grateful for the assistance received from the Centre for Development Studies in Trivandrum, Kerala, and the financial support for this research project from the Swedish Agency for Research Cooperation with Developing Countries (SAREC).
} 
just like my granddaughter. Here in our village it is as if the girls are born with the cashew [shelling] sticks in their hands.

Kavitha, woman of the Kurava caste, born about 1920 in Quilon, Kerala (formerly Travancore) $^{\mathrm{I}}$

In the late nineteenth century, the Indian religious leader, Swami Vivekananda, gave the name "the madhouse of India" to the princely state of Travancore (which in 1956 became part of the newly formed state of Kerala). He was referring to the rigid caste rules that existed there. In the I930s, high-caste people still measured very carefully the distance from which they had seen an "untouchable" person to decide whether or not they had to undergo a ritual of purification. ${ }^{2}$ Those were years of abject poverty and starvation among a large part of the population - especially the lower castes - but it was also a time of protest against the existing social hierarchy and a period which saw the formation of trade unions.

Forty years later, a new concept, the "Kerala Model", emerged among development researchers worldwide. ${ }^{3}$ Achievements in human progress, in spite of a lower GNP per capita than other parts of India and in spite of a lack of industrialization, were first documented in the mid-I970s when a group of scholars in Trivandrum, the capital of Kerala, concluded that Kerala "has certainly some lessons for similar societies seeking social and economic advancement".4 They highlighted positive achievements in human development and quality of life, and especially stressed successes in health and education.

With regard to such social indicators as literacy, infant mortality, life expectancy, and birth rates, Kerala is far above low-income countries, and can even be favourably compared with some Western countries. It has also been pointed out that the gender difference in Kerala, in contrast with

I. Some workers expressed fear that their opinions would come to the attention of factory owners, so all workers names are pseudonymous.

2. Interview, I 9 December 1997 with K. Bhanu, former journalist, born in I9I 3, Quilon district; interview, I4 September 1999 with K. Chellappan, former trade-union leader, born in I9I4, Quilon district.

3. For a discussion of the Kerala Model, see Economic and Political Weekly, 25 (1990), 35-36, pp. 195 I-2019, 2053-2107; Robin Jeffrey, Politics, Women and Well Being: How Kerala Became "A Model" (New Delhi, I992); "The Kerala Model of Development: A Debate, Part I and 2", Bulletin of Concerned Asian Scholars, 30 (1998), 3, pp. 25-36; 4, pp. 35-52; Monica Erwér, “Development Beyond the 'Status of Women': The Kerala Model from a Gender Perspective, South India” (M.Phil., Göteborg University, Department of Peace and Development Research, 1998); M.A. Oommen (ed.), Kerala's Development Experience, 2 vols (New Delhi, 1999); Govindan Parayil (ed.), Kerala, the Development Experience: Reflections on Sustainability and Replicability (New York, 2000).

4. United Nations, Poverty, Unemployment and Development Policy: A Case Study of Selected Issues with Reference to Kerala (New York, 1975), p. I 54. 
most other parts of India, is negligible.' To explain Kerala's development, particular importance has been attached to the history of the region. ${ }^{6}$ Its advances have also been attributed to a radical strategy of redistribution, a high degree of awareness among the people, and to strong and militant social movements. ${ }^{7}$

It is in the context of the rapid development from a strict hierarchical society to the Kerala Model and its radical reforms that we should place the three generations of cashew workers which are the focus of this study. ${ }^{8}$ Beginning with a few cashew nut factories in the mid-I920s, the number of factories rapidly increased, until cashew workers were the largest group of registered factory workers in the region. At any given time, they have represented from thirty to fifty per cent of the formal factory workforce in Kerala, and today number more than 200,000 workers - of whom ninetyfive per cent are women. ${ }^{9}$ In no other state in India do we find such a large proportion of women in registered factories. ${ }^{10}$

Foreign trade (including the cashew trade) has long been regulated by the central government of India. Both state government and central government have intervened to control the cashew industry in various ways. In 1970, the state of Kerala began to take over ownership of cashew factories. These ultimately peaked at seventy state-owned factories, employing about one-third of the total number of cashew workers in the jurisdiction. Cashew workers thus came into a close relationship with the state of Kerala, which functioned both as an agency implementing labour laws, and also as an employer. State intervention in connection with women's work in low-income countries have mainly been seen in the socalled "world market factories" and export-processing zones that emerged in the late I960s and early I970s. Scholars have stressed the suppressive nature of such interventions, which mainly served to increase export,

5. Richard Franke and Barbara Chasin, Kerala: Radical Reform as Development in an Indian State (San Francisco, CA, I989), pp. Io ff.; M.D. Morris, Measuring the Condition of the World's Poor: the Physical Quality of Life Index (New York, 1979), pp. xi, 64, I38-145; Amartya Sen, Development as Freedom (Oxford, 1999), pp. 21-24, 46-49.

6. Jeffrey, Politics, Women and Well-Being.

7. Franke and Chasin, Kerala: Radical Reform as Development.

8. Several scholars have argued against the concept of "Kerala Model", preferring to name it the "Kerala experience" in order to stress that it is not a model that can be applied anywhere. For a discussion of this and a defence of the concept of the "Kerala Model", see Govindan Parayil (ed.), Kerala, the Development Experience, pp. I-I s.

9. Government of Kerala, Economic Review (Trivandrum, 1960-1998).

Io. The figure at an all-India level has remained fairly constant at around ten per cent during the postcolonial era. Government of India, Statistical Profile on Women Labour (Simla, 1985), p. 33; Government of India, Statistical Profile on Women Labour (Simla, 1998), p. 23. 
finding that they have worked against women. ${ }^{\text {II }}$ Kerala state's role in the cashew industry may be a paradoxical one, aiming to protect workers from exploitation, while being driven to increase exports of this extremely important commodity because of its value for earning foreign exchange on the competitive global market. ${ }^{12}$

The first cashew workers' trade union was registered in 1939, and by the I950s it was estimated that seventy-five per cent of all cashew workers were union members. ${ }^{13}$ According to trade union leaders, this figure has since increased to almost ninety-five per cent. ${ }^{14}$ With regard to strike activities, the cashew workers - especially up to the mid-I970s - have been extremely militant, as reflected in official statistics. ${ }^{\text {Is }}$

The Kerala cashew workers exhibit great potential for power, in contrast to the stereotype of Third-World women, who are most often portrayed as illiterate, powerless victims. ${ }^{16}$ Nevertheless, it was recently stated that seventy-five to ninety per cent of these cashew workers live below the

I I. Diane Elson and Ruth Pearson, "The Subordination of Women and the Internationalisation of Factory Production”, in Kate Young, Carol Wolkowitz, and Roslyn McCullagh (eds), Of Market and the Market: Women's Subordination in International Perspective (London, 1981), pp. I45-I66; Folke Fröbel, Jürgen Heinrichs, and Otto Kreye (eds), The New International Division of Labour (Cambridge, I980); Swasti Mitter, Common Fate, Common Bond: Women in the Global Economy (London [etc.], 1986), especially pp. 25-64; Guy Standing, "Global Feminization through Flexible Labour”, World Development, I7 (1989), pp. 1077-1095; Cynthia Enloe, Bananas, Bases and Beaches: Making Feminist Sense of International Politics (London, 1990). For a contrasting view, see Linda Lim, “Women's Work in Export Factories: The Politics of a Cause", in Irene Tinker (ed.), Persistent Inequalities: Women and World Development (New York, 1990), pp. I0I-I I9.

I 2. During the last fifty years their proportion in the value of the total exports from Kerala has fluctuated between nineteen and thirty-three per cent. T.M. Thomas Isaac, "The Trend and Pattern of External Trade of Kerala", in B.A. Prakash (ed.), Kerala's Economy: Performance, Problems and Prospects (New Delhi, 1994), pp. $37 \mathrm{I}$ ff. It was recently stated that cashew was the most important earner of foreign exchange among the agricultural products of India. See Government of Kerala, Economic Review (Trivandrum, I995), p. 100; Cashew Bulletin (Cochin, I995), 8, p. I.

I3. Balan K. Pillai, "The Economic Impact of Collective Bargaining on Cashew Industry in Kerala" (Ph.D., University of Kerala, I986), p. I 58.

I4. Interview, I3 August 1998, with R.S. Unni, former trade-union leader in Quilon; interview, I 2 January 1998, with J. Chitharanjan, former trade-union leader in Quilon.

I 5. Government of Kerala, Quarterly Bulletin of Statistics (Trivandrum, 1959); Government of Kerala, Statistics for Planning (Trivandrum, 1972, 1988, and 1993).

i6. Chandra Talpade Mohanty. "Under Western Eyes: Feminist Scholarship and Colonial Discourse", in Chandra Talpade Mohanty, Ann Russo, and Lourdes Torres (eds), Third World Women and the Politics of Feminism (Bloomington, IN, 1991), pp. 5i-80. For discussions on "Third-World Women" see Haleh Afshar and Bina Agarwal (eds), Women, Poverty and Ideology in Asia (London, 1989); Hilary Standing, "Employment", in Lise Östergaard (ed.), Gender and Development: A Practical Guide (London, 1992), pp. 57-75; Janet Momsen Henshall, Women and Development in The Third World (London, I99I), pp. 44-92. 
poverty line, representing a figure some three times greater than that of the total population in the region. ${ }^{17}$

My main interest in the study of the cashew workers of Kerala has been to explore the dynamics of the workplace and subsequent changes that have affected their lives. A pivotal question has been how factory work, along with such other factors as gender ideologies and marriage patterns, have shaped identities with regard to class, caste, and gender. A central point of departure is that hegemonic ideologies, institutional practices, and everyday social and cultural experiences intersect in the construction of these identities.

\section{CLASS, GENDER, CONSCIOUSNESS, AND IDENTITIES}

E.P. Thompson's impressive study, The Making of the English Working Class, has served as a source of inspiration for a whole generation of scholars interested in class formation, social struggles, and the transformation of societies during the industrial era. The importance of his seminal work lies primarily in its rejection of structural determinism, and its emphasis on agency "from below". Thompson asserts that people's daily and shared experiences, shaped by productive relations, lead them to identify common interests. ${ }^{18}$ As pointed out by Leela Fernandes, in spite of the stress on noneconomic factors, Thompson's analysis results in the perception of a unified and homogenous category of class, which has severe consequences when adding gender to the analysis. ${ }^{19}$

Thompson does not distinguish between class consciousness and class identity. I here define class consciousness as an awareness of the conflict between capital and labour, and the need to express class demands. Social identity - the sense of societal belonging - is more complex and, since individuals have overlapping and fragmented identities, has several levels. ${ }^{20}$

Joan W. Scott has been of great importance for those interested in gender studies. Scott's methodology of deconstruction, in identifying how gender discourses were constructed through a language of dichotomies relating to masculinity and femininity is, in my view, fruitful, although I do not adhere to her opinion that there is no meaningful experience or social

17. The Kerala Cashew Workers Welfare Board in Quilon estimated this in 2000. For Kerala in general, see M. Mohandas, "Poverty in Kerala”, in Prakash, Kerala's Economy, pp. 78-94, 87-88. See also K.P. Kannan, "Poverty Alleviation as Advancing Basic Human Capabilities", in Parayil, Kerala, the Development Experience, pp. 40-65.

I 8. E.P. Thompson, The Making of the English Working Class (Aylesbury, 1980).

19. Leela Fernandes, Producing Workers: The Politics of Gender, Class, and Culture in the Calcutta Jute Mills (Philadelphia, PA, 1997), p. Iо.

20. For a discussion of the concept of identity, see Harriet Bradley, Fractured Identities: Changing Patterns of Inequality (Cambridge, I997), especially pp. 23-27, 202-2 I4. 
reality outside that of discourse. ${ }^{2 \mathrm{I}} \mathrm{My}$ standpoint with regard to postmodernism is to advocate a linking of the study of languages and discourses to social practice. ${ }^{22}$ It appears crucial, when elaborating upon the question of gendered class consciousness and identities, to combine the two spheres. Identities are not only formed by ideologies (which are broader than both ideas and discourses) - they are also experienced and shaped in the practices and materiality of everyday life. Following Harriet Bradley, we need "a both/and approach: materiality and meaning". ${ }^{23}$ The position taken in this paper is to keep a feminist materialist perspective, while allowing entry to some postmodern ideas.

So-called "subaltern historians", like Dipesh Chakrabarty, and the postcolonial theorist, Gayatri Spivak, accused modernist theories of being Western constructions which have no relevance for India, with its entirely different history. ${ }^{24}$ Chakrabarty argues that concepts such as class consciousness, capital, and proletariat cannot be used to analyse Indian society, because India lacked the bourgeois ideas of citizenship and equality so central to the West. Instead, he advocates much greater attention being paid to specific cultural aspects. ${ }^{25}$

The subaltern historians, however, have come under severe criticism. For example, the Indian labour historian, Ranajit Das Gupta, is of the opinion that Chakrabarty's "rethinking" is but a conservative orientation, embracing cultural determinism in which the subjects disappear as

\footnotetext{
21. Joan W. Scott, Gender and the Politics of History (New York, I988).

22. Neville Kirk has argued that Joan Scott, along with other postmodernists like Gareth Stedman Jones and Patrick Joyce, has fallen into an "epistemological trap" by failing to make a distinction between "existence and interpretation/understanding"; Neville Kirk, "History, Language, Ideas and Postmodernism", in Keith Jenkins (ed.), The Postmodern History Reader (London [etc.], 1997), pp. 333-334.

23. Bradley, Fractured Identities, p. 9.

24. Dipesh Chakrabarty, Rethinking Working-Class History, Bengal I 890-1940 (New Delhi, I989); Gayatri Chakravorty Spivak, The Post-Colonial Critic: Interviews, Strategies, Dialogues (London, 1990).

25. For a critical discussion of the subaltern studies see, for example, Rosalind O'Hanlon, "Recovering the Subject: Subaltern Studies and Histories of Resistance in Colonial South Asia", Modern Asian Studies, 22 (1988), pp. I89-224; Gyan Prakash, "Writing Post-Orientalist Histories of the Third World: Perspectives from Indian Historigraphy", Comparative Studies in Society and History, 32 (1990), pp. 383-408; Rosalind O'Hanlon and David Washbrook, "After Orientalism: Culture, Criticism, and Politics in the Third World", Comparative Studies in Society and History, 34 (1992), pp. I4I-I67; Gyan Prakash, "Can the 'Subaltern' Ride? A Reply to O'Hanlon and Washbrook”, Comparative Studies in Society and History, 34 (1992), pp. I68I 84 .
} 
agents. ${ }^{26}$ Subaltern historians have also been censured for producing the history of elites, ${ }^{27}$ and recently for a neglect of gender perspectives. ${ }^{28}$ In essence, Chakrabarty sees failures to unionize or to develop class consciousness as aspects of Indian society strongly linked to cultural inheritances from the past. From a gender perspective, however, such arguments may, in fact, be flawed, and the polarization "traditional vs. modern" inadequate. ${ }^{29}$

Recently, several feminist researchers in the fields of history, anthropology, and development, as well as political scientists, have highlighted the failure of earlier analyses of caste and class identities to include gender. It has been stressed that interconnections and boundaries between such categories as class, caste, and gender are complex and contested, and that the construction of categories is an act of exerting power..$^{30}$ The argument regarding the impact of ideologies of female domesticity and hegemonic discourses in the construction of identities has been forcefully developed, for example, by Samita Sen with regard to colonial India, and Leela Fernandes and Karin Kapadia with regard to contemporary India. ${ }^{3 \mathrm{I}}$

A central insight into postmodern approaches to the concept of identity is that identities are fluid and continguent, rather than fixed and unchangeable. People have multiple identities which fluctuate, overlap, and are fragmented, dynamic, ambiguous, and sometimes conflicting. It may,

26. Ranajit Das Gupta, "Indian Working Class and Some Recent Historiographical Issues", Economic and Political Weekly, 3 i:8 (1996), pp. L-27ff.; See also Vinay Bahl, "Relevance (or Irrelevance) of Subaltern Studies", Economic and Political Weekly, 32:23 (1997), pp. I333-I334; Vinay Bahl, "Caste or Class", International Journal of Contemporary Sociology, 27 (1992), pp. 227-249. For a criticism of Chakrabarty's use of official reports to interpret the workers' identity see Amiya Kumar Bagchi, "Working Class Consciousness", Economic and Political Weekly, 25:30 (1990), pp. PE-54-60.

27. Ramachandra Guha, "Subaltern and Bhadralok Studies", Economic and Political Weekly, 30:33 (1995), pp. 2056-2058; Richard M. Eaton, “(Re)imag(in)ing Otherness: A Postmortem for the Postmodern in India”, Journal of World History, i I (2000), pp. 57-78.

28. Himani Bannerji, "Projects of Hegemony: Towards a Critique of Subaltern Studies 'Resolution of the Women's Question'”, Economic and Political Weekly, 35 (2000), pp. 902-920. 29. Fernandes, Producing Workers, p. Is.

30. Karin Kapadia, Siva and Her Sisters: Gender, Caste, and Class in Rural South India (Boulder, CO [etc.], I995); Fernandes, Producing Workers; Amrita Chhachhi and Renée Pittin, "Multiple Identities and Multiple Strategies: Confronting State, Capital and Patriarchy", in Ronaldo Munck and Peter Waterman (eds), Labour Worldwide in the Era of Globalization: Alternative Union Models in the New World Order (New York, 1999), pp. 64-79; Kalpana Ram, Mukkuvar Women: Gender, Hegemony and Capitalist Transformation in a South Indian Fishing Community (New Delhi, I992).

31. Samita Sen, Women and Labour in Late Colonial India: The Bengal Jute Industry (Cambridge, 1999); Fernandes, Producing Workers; Karin Kapadia, "Gender Ideologies and the Formation of Rural Industrial Classes in South India Today", in Jonathan P. Parry, Jan Breman, and Karin Kapadia (eds), The Worlds of Indian Industrial Labour (New Delhi, I999), pp. 329352 . 
for example, conflict to be of high caste and yet be a member of the working class, to be a woman and a worker, to be a mother and a trade union leader. Identities are historically and culturally formed, i.e. they are nonessential and cannot be derived from an external referent.

The British sociologist, Harriet Bradley, has conceptualized different forms of social identity in a useful way by identifying three levels on which they may function: passive, active, and politicized. Having a passive identity means that a person or social group does not particularly think about their identity. It is, in a sense, a potential identity, only to be activated when specific events occur. An active identity has reached the consciousness of individuals who are, for the most part, aware of belonging to a specific, identified group - whether class, gender, ethnicity, or any other affiliation. According to Bradley, active identities are promoted when one experiences discrimination. An identity becomes politicized when it is the basis for collective action. ${ }^{32}$ To the politicized identity we may add a further qualification - central or peripherical identity: having the feeling of empowering activity or being led.

\section{METHODOLOGY: ORAL HISTORY FROM BELOW}

Gayatra Spivak has asserted that the "subalterns" are already positioned in a variety of (Western) discourses. Thus, she answers her own provocative question, "Can the subaltern speak?" with a "No". ${ }^{33}$ However, it may be that they are, in fact, able to speak, and we should respect their own interpretations of their lives and memories. In this regard, E.P. Thomson's perspective "from below" still seems fruitful. If the discourses were so anticipatory and obstructionist, one would not be able to write meaningful history at all.

Despite the risks involved in producing "oral history", 34 i.e. the researcher's role and the informants' way of remembering and narrating, I took it as my task to go to "the Others" in order to analyse material conditions and workplace relationships, explore their understanding of ideas, and their ways of talking and thinking - all of which have provided meaning to their strategies and to the formation of identities.

The feeling of being an outsider (a "Westerner"), a stranger, or even an exploiter, required a lot of effort to overcome. The fact that some people told me my endeavour was impossible, not having been born and bred into

32. Bradley, Fractured Identities, pp. $25-26$.

33. Gayatri Chakravorty Spivak, "Can the Subaltern Speak?", in Patrick Williams and Laura Chrisman (eds), Colonial Discourse and Post-Colonial Theory (New York, 1993).

34. For a comprehensive discussion on oral history see Robert Perks and Alistair Thomson (eds), The Oral History Reader (London [etc.], I998). 
the Keralite culture, distressed me, but soon became a strong motivation for carrying out this study.

After several short visits during the early I990s, each lasting a month or two, I returned to Kerala in 1997 for longer stays. For the past four years Kerala has been my second home. I have lived there for about twenty months altogether. Working in Kerala in close collaboration with an indigenous research assistant and friend - we shared the same house, spending days as well as evenings together - made me overcome my initial trepidation, and I began to see that being an outsider had certain advantages. I came to realize that there were indigenous researchers who, because of their class, caste, or gender, were actually greater outsiders than I. One illustration of the distortions class position can occasion is Jayati Lal. She returned home to India, where she had been born, spent her childhood, and gone to the university. Coming back from the West as a researcher to study relations between factory workers and owners, she found her privileged class position acted as a hindrance. ${ }^{35}$ As a foreigner who was not part of the social hierarchy, I found my class position less of a burden than Jayati Lal did. It may well be that, whatever it is we study, unless we are writing our own autobiographies, we are outsiders, because of such factors as the epoch we are living in, our class, education, gender, ethnicity, religion, generation, and other elements. Kirin Narayan has called for a discarding of the dichotomy outsider/insider, and a focusing instead on "the quality of relations with the people we seek to represent in our texts." ${ }^{6}$ It seems clear that although a person may be born in the West, it does not mean one necessarily has to act and think as the stereotype of a Westerner. As Chandra Mohanty has argued, many Third-World women writing on issues concerning women in their own regions have created stereotypes of Third-World women. ${ }^{37}$

The present study of the cashew workers of Kerala is based on personal interviews ${ }^{38}$ and traditional written or printed archival material in English, such as correspondence, government reports, and statistical surveys. In addition, trade-union chronicles, historical accounts, daily newspapers,

35. Jayati Lal, "Situating Locations: The Politics of Self, Identity, and 'Other' in Living and Writing the Text”, in Dianne Wolf (ed.), Feminist Dilemmas in Field Work (New York, 1996), pp. I85-2I 4 .

36. Kirin Narayan, "How Native Is a 'Native' Anthropologist?", in Louise Lamphere, Helena Ragoné, and Patricia Zavella (eds), Situated Lives: Gender and Culture in Everyday Life (New York, 1997), pp. 23-39.

37. Mohanty, "Under Western Eyes".

38. Interviews with factory owners, managers, civil servants, politicians, and trade-union leaders at higher levels were normally carried out in English, whereas interviews with workers were carried out in collaboration with an interpreter. I never learned the local language to the extent that I could carry on a deep conversation in an adequate way, but I learned enough to create an entré for my efforts and, of course, to amuse people with my mistakes. 
and other local material were reviewed and excerpted in conjunction with my research assistant, who translated relevant parts into English. I visited numerous cashew factories and spent much time in the dwellings of cashew workers. Forty-five interviews with different generations of cashew workers were conducted in their homes. I visited each family at least twice, and in most cases three to six times, which proved a fruitful approach, since new memories and insights always emerged. Obviously, frequent visits also led to mutual trust and understanding.

As a foreigner, accompanied by a sensitive interpreter with great social ability in interacting with the rural poor, I was afforded the opportunity of discussing everything, from the most obvious or trivial, to the most forbidden issues. I was not a threat, since I had no power - neither in the trade unions nor among the factory owners; nor was I considered someone in any way involved in their society. I could, for example, pose the most awkward questions - about caste, sexuality, or other sensitive matters which people do not normally discuss.

\section{THE CASHEW FACTORIES}

British and American companies began to establish cashew processing factories in British India in the mid-r920s. The absence of labour laws and the presence of other circumstances favourable to factory owners led to a wildfire expansion of cashew operations in the r930s and I940s, in and around the city of Quilon in Travancore. The region soon became the largest centre of cashew-nut processing in the world. Indigenous entrepreneurs quickly dominated and controlled the industry. The very last foreign-owned factory was sold in the ig6os.

Today almost 400 registered cashew factories, each of them employing 300 to I,000 workers, are centralized in a relatively small area. A total of about 200,000 workers are registered, and the number may be considerably higher. The cashew workers are the largest group of registered factory workers in Kerala and have been so for the last fifty years. The factories are not only geographically concentrated, but the majority of the private factories are in the hands of a few wealthy and politically powerful families.

The working process, which is mainly manual, has not changed very much since the I930s. It involves several steps, beginning with the dirtiest - roasting and shelling - and ending with the cleanest, the grading of white cashew kernels. A very pronounced caste division of labour, with a correlation between the degree of cleanliness of the particular operation and the rank in the caste hierarchy of the worker, was evident in the early cashew factories. This division has, to a great extent, continued.

In the late r 930 s the proportion of male workers in the factories was about twenty-five per cent. Almost without exception, they belonged to 


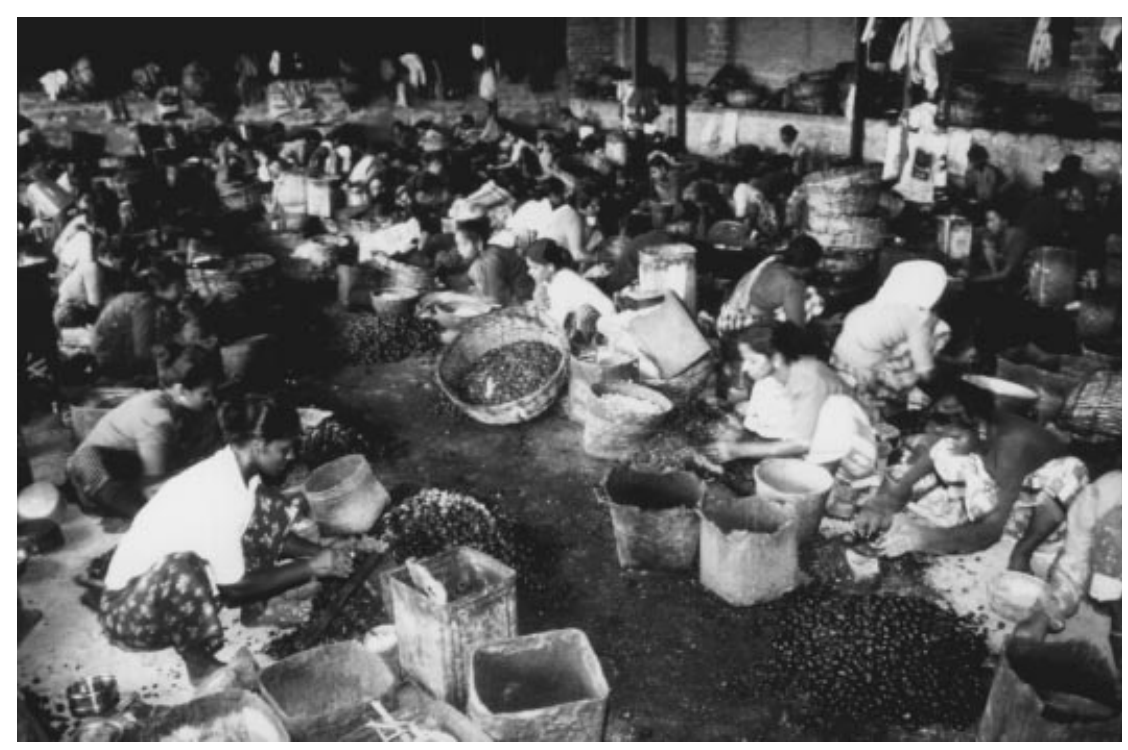

Figure I. Shelling sections are often dirty and unhealthy places. The majority of the women working here belong to the lowest castes.

Copyright photograph Anna Lindberg

the lowest castes (the former "Untouchables"). They did roasting and shelling, the two operations considered the most unclean because of how physically dirty they are. These two processing areas were gender-mixed, although men dominated roasting and women shelling. In other sections, the gender division of labour was almost total, and it was here that the higher castes worked. The proportion of high-caste women was fairly small. It is important to note that where men and women did work together, they invariably belonged to the lowest castes and were, for the most part, equally paid.

Several studies on Indian industrial labour stress the declining number of women in the registered work force during the twentieth century. 39 However, from the late i940s on, the cashew factories show the reverse pattern..$^{\circ}$ During the late 1950 s the proportion of male workers was stabilized at about five per cent, and males exclusively performed operations which were considered strenuous or involved the use of machines. This contrasted with the female sections, where dexterity was

39. Sen, Women and Labour in Late Colonial India. For a general discussion of reasons for the declining employment of women, see Sujata Gothoskar (ed.), Struggles of Women at Work (New Delhi, I992), pp. 4-I I.

40. This tendency has also been seen in other labour-intensive industries in India a few decades later. Several examples are given in the contributions in Nirmala Banerjee (ed.), Indian Women in a Changing Industrial Scenario (New Delhi, 199r). 


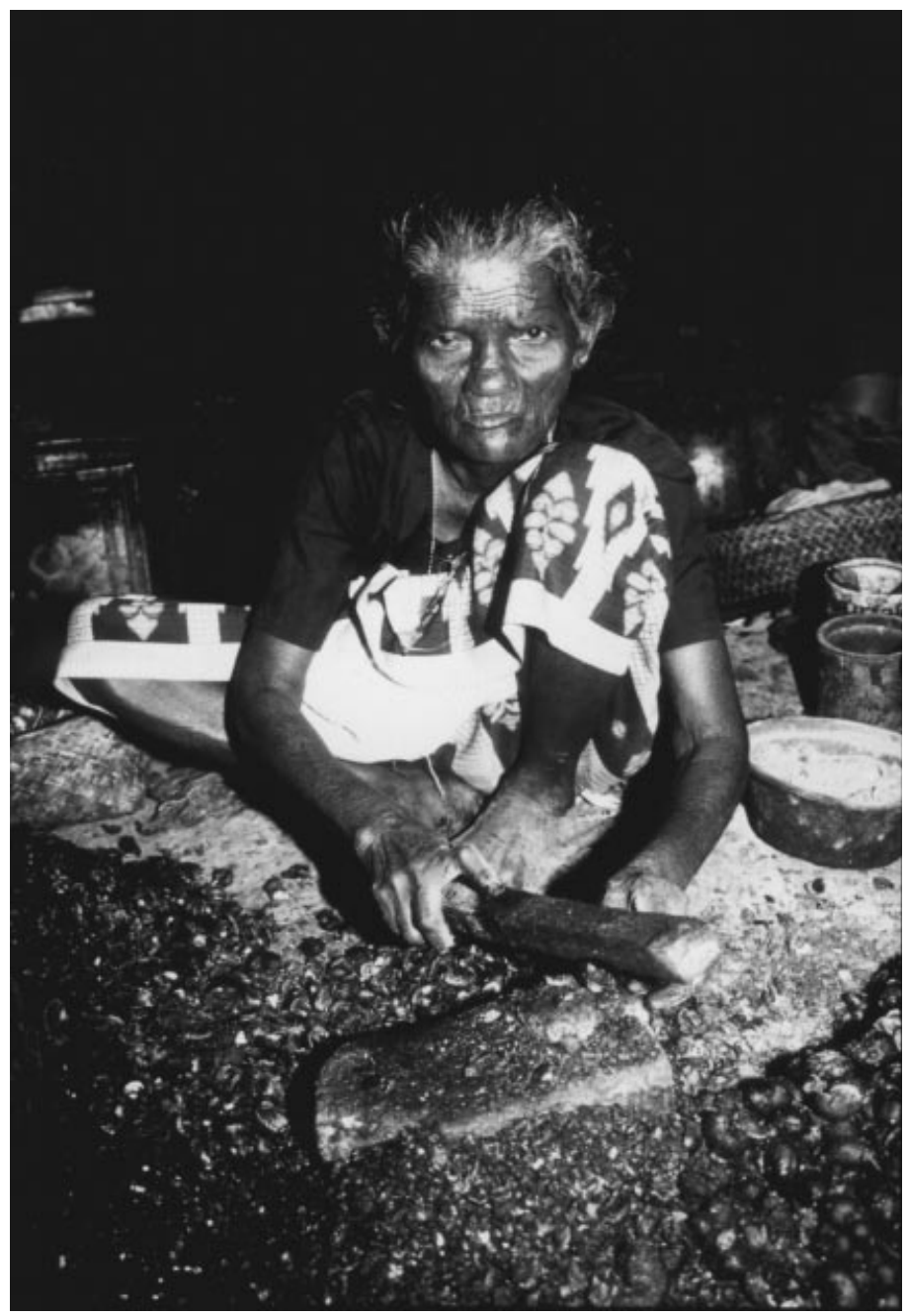

Figure 2. This low-caste woman has been shelling cashew nuts for more than seventy years. She is no longer a registered worker and receives no fringe benefits. Her working speed has slowed down and she can only produce one-third of her former daily output, earning her about fifteen rupees per day.

Copyright photograph Isak Lindberg

prized as the most valuable skill. A strict gender division had evolved in the workplace, consistently defining women as dextrous and patient "temporary" workers, in contrast to the strong males, who were considered the actual breadwinners. In the early cashew factories, all workers were per diem employees and the wage system was based on piecework. Gradually, most of the male workers were given monthly wages and were thus 


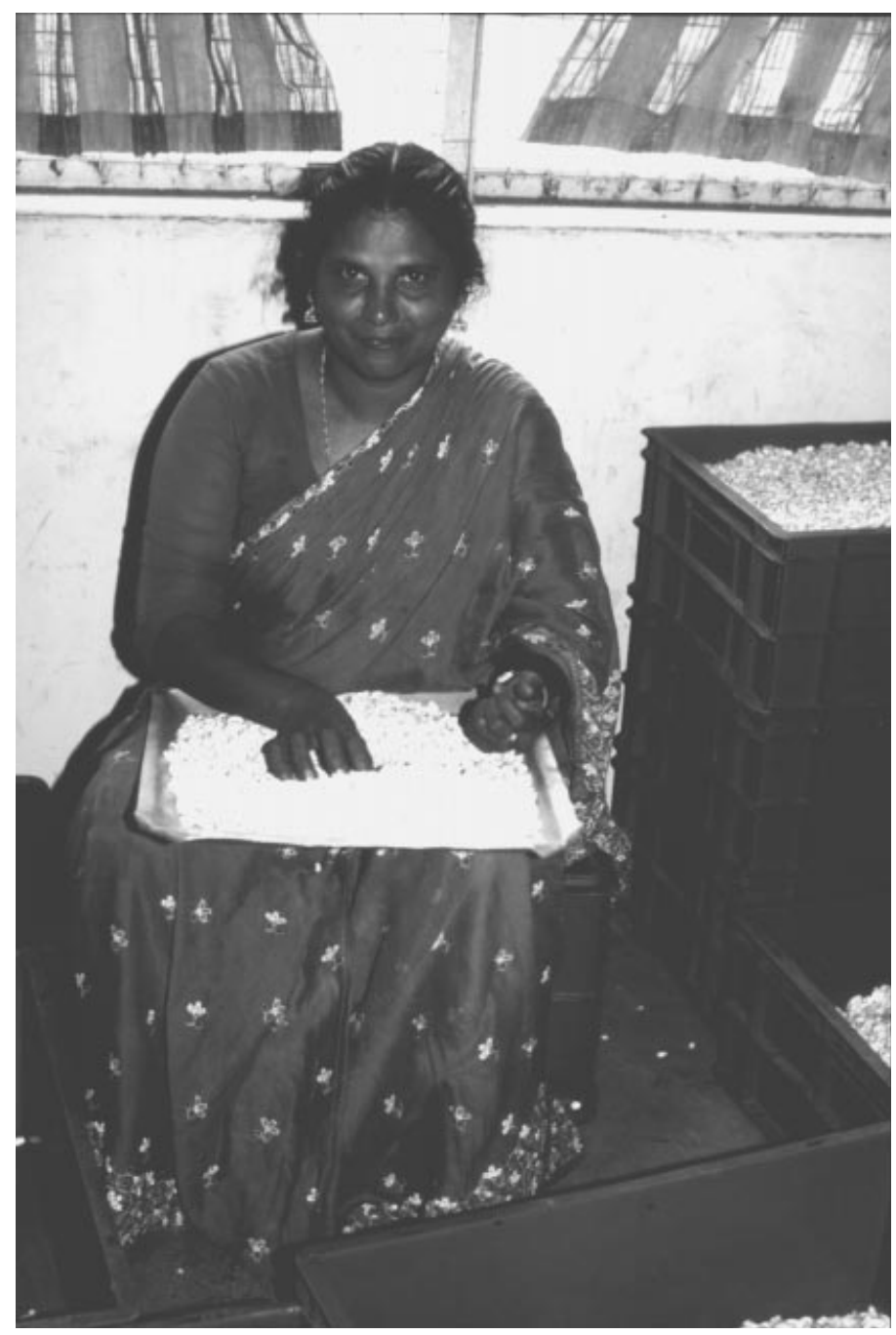

Figure 3. A high-caste woman in the grading section. The grading sections are lighter, cleaner, and less unhealthy than the shelling sections. Almost without exception, women who work here belong to the higher castes. Nevertheless, their wages are as low as wages in the shelling section: gender, not caste, determines wages.

Copyright photograph Anna Lindberg

unaffected by the seasonal character of the industry - an element which has become increasingly pronounced. The gap between female and male wages has steadily widened, if one looks not at statutory daily minimum wages, but at annual wages, including such fringe benefits as unemployment compensation. 
Trade unions have played a decisive role in the process of wage increases by trying to establish financial security for male workers as breadwinners. This has been a declared goal of the unions, institutionalized when minimum wages were introduced in the i950s. It was established that calculations of such a minimum should be based on the Indian Report of Fair Wages, which openly stated that women were to receive only twothirds of the wage given to men. In cases where men and women carried out the same work, a strict gender division of labour was recommended in order to maintain the stipulated wage difference between male and female workers without obvious injustice. ${ }^{\mathrm{I}}$

Working conditions in the early cashew factories were extremely harsh, with unbridled, unprecedented exploitation, starvation wages, and a great deal of child labour. Recruitment occurred through a system of contracting with supervisors, and sometimes even poor roasters were given the chance to raise themselves to a higher position by bringing in poor, landless agricultural workers from rural areas. These workers were accommodated in simple sheds. In Kilikolloor, a village near Quilon which can be taken to represent cashew villages per se, hundreds of such sheds could be seen in the I930s and I940s. Their occupants were considered among the poorest in the country and also at the lowest level of the social hierarchy. In those days, work in the cashew factories was tantamount to a full-time job and all factories were classified as perennial. Nonetheless, through the I940s and early i950s, factory owners persistently asserted that cashew workers were mainly agricultural workers who worked in their factories "on the side". Later, the same workers were redefined as "housewives" who were maintained by their husbands. Thus, such individuals were not categorized as totally dependent on factory work for their living, but were classified more as semiproletarized workers for whose reproduction the employers did not need to take responsibility. ${ }^{2}$

In response to the growing trade unions and stricter labour laws, factory owners resorted to two main strategies. The first was to decentralize their production into cottage processing and unregistered factories. When the Kerala government legislated against this practice in 1967 , the owners' second move was to shift the factories to the neighbouring state of Tamil Nadu, where trade unions were weaker and the state government's attitude more favourable to the factory owners. Since that time, low wages, child

\footnotetext{
4I. Government of India, Report of the Committee on Fair Wages (Simla, I954); Government of Travancore-Cochin, Kerala Report of the Minimum Wages Committee for Cashew Industry (Trivandrum, 1953), pp. 19-20.

42. For a discussion of semiproletarians, see Immanuel Wallerstein, Historical Capitalism (London, 1983). For a similar discussion of housewives, see Claudia von Werlhof, "Women's Work: The Blind Spot in the Critique of Political Economy", in Maria Mies, Veronika Bennholdt-Thomsen, and Claudia von Werlhof (eds), Women: The Last Colony (New Delhi, I988).
} 
labour, and other violations of labour laws have been a constant feature of the cashew factories in Tamil Nadu. There is also ample evidence of cashew factory owners in that state resorting to corruption and bribery when factory inspections have not been to their liking.

The cashew factories did not shift entirely to Tamil Nadu. Powerful owners kept a number of factories, employing several thousand workers, in operation on both sides of the state border - an optimal situation for them. The threat of moving factories to a neighbouring state was itself enough to frighten workers, trade unions, and politicians in the two states, thereby lowering wages and allowing all kinds of labour laws to be violated.

In Kerala, the number of factories, as well as the number of workers, has increased since the I960s, while the annual working days per employee has dwindled so greatly that today all female cashew workers - the preponderance of the workforce - are considered only seasonal workers. The seasonal character of cashew processing is even more pronounced in the state-owned factories, where a lack of raw cashew nuts has been a constant problem.

Through the struggle of trade unions, the cashew workers in Kerala have achieved many rights, such as bonuses, maternity benefits, pensions, and welfare funds. Unfortunately, far from all cashew factory workers enjoy these rights, since a minimum number of annual working days is required in order for workers to be covered by the labour laws. Regulations are still often violated in the private factories. In the I990s, clandestine factories, so-called kudivarappus, which had never totally disappeared, flourished as never before. In such factories, workers are paid about one-third to onehalf of the minimum wage and receive no fringe benefits. These same workers seek out employment in registered factories when those are in operation. Unregistered factories are sometimes owned or leased out by the same people who are owners of the registered factories.

In consequence of the above, one cannot speak of a dualism of formal versus informal sectors, neither with regard to workers, nor to the factory owners. ${ }^{43}$ It has been very common that young girls start to work in unregistered factories at the age of thirteen or fourteen, so that when they enter the registered factories at the age of eighteen they are already skilled. A large number of old women are also encountered in the plants. It has long been the custom, even in the registered factories, to keep workers off the rolls, thus paying them less than the stipulated minimum wage, and no fringe benefits - which is why one must take account of an informal sector 
within the registered factories. Those workers who are paid off the books are often the very young or those above the official retirement age. As a result, very many workers who are as yet untrained, or who have lost some of their former agility due to age, constitute an underground of secondclass workers with lower wages and fewer benefits.

If one poses the question of how this steady violation of labour laws among the largest single group of registered workers has been possible in Kerala - a state with militant trade unions - one must look to the power of capital. The footloose nature of capital has substantially weakened the workers' bargaining power, and it is clear that trade unions have met with severe opposition. Nevertheless, in other sectors of the economy (among the beedi workers, for example), a more successful labour movement has been documented in Kerala, in spite of the same opportunity for capital to flee to other states. ${ }^{44}$ The beedi industry has been supported by the Kerala state, just as the cashew industry has. In the state-owned cashew factories, labour laws continue to be violated, and the possibility of workers exerting their influence over conditions in the factories have been limited. The largely male-dominated beedi workers launched workers' cooperatives to overcome these problems. In the early I980s, such cooperatives were undertaken in the cashew sector as well, the vast difference between the two being that in the cashew sector such cooperatives were formed "from above" by politicians. The rank-and-file were disregarded and to this day have not been asked to participate in the decision-making process because, so it was argued, they are illiterate. In fact, this is a fallacy, as several studies show that since about 1970 the majority of cashew workers have become literate. Rather, cashew workers have been excluded from wielding any influence due to their gender. The success of the beedi cooperatives and the relative failure of the cashew cooperatives appear linked to the ideology of male breadwinners, and to the corresponding view of women as only supplementary providers.

The question of why women workers have been so prone to accept employment in unregistered factories continued to puzzle me. During interviews, I found that women were generally quite aware of their rights, and seemed to have been for a long time. They also expressed their class consciousness quite clearly. Thus, aside from the power of capital, we must consider several other factors if we seek to explain the failure of the cashew workers (to some extent at least) in securing their own rights. One such arena is the nature of the trade unions, and another is the social and cultural construction of femininity and masculinity.

44. Beedis are small, hand-rolled Indian cigarettes. See T.M. Thomas Isaac, Richard W. Franke and Pyaralal Raghavan, Democracy at Work in an Indian Industrial Cooperative: The Story of Kerala Dinesh Beedi (New York, 1998). 


\section{THE TRADE UNIONS}

During the industry's early phase, when a great number of low-caste men worked in the cashew factories, they and their female co-workers (both being of the lowest castes) became the first members of the emerging trade unions. In fact, the social struggle in Kerala had started in caste-based organizations. In the I940s, however, leaders strongly argued for the abolition of caste as a category, putting a stress on class struggle instead. The resistance by factory owners was tenacious in the I940s, and one way they sought to prevent workers from joining the union was to uphold and even cultivate caste segregation. Husbands of female workers of higher castes were advised to prevent their wives from joining unions because this would cause them to commingle with men of lower castes.

The rather strict caste division of labour which is perpetuated in the cashew factories is partially explained by the custom of mothers securing jobs for their daughters, and girls then learning the needed skills from their mothers. But one must also take into account perceptions among the workers themselves that, as several informants told me, lower castes are "more used to carry out dirty work".

Male workers were considered to be "trouble-makers" and factory owners often either dismissed them, or would not re-employ them after seasonal closures. Simultaneously, male workers who remained in "female-defined" sections began to be characterized as "nonmen". They were said to be of an age that rendered them weak (very young or old) and not "able-bodied", i.e. rather like women.

In spite of resistance on the part of factory owners, several victories were won by trade unions in the I940s and 1950s. In 1946, the cashew factories were included under the Factory Act and child labour was prohibited; in 1953, minimum wages were introduced. One female worker, Radha, born in 1928, described the I950s in the following way: "We were quite happy at that time. We felt that the state, through the Labour Commissioner and factory inspection, were on our side. We were on the march - men, women, trade union leaders, and politicians. We had a firm belief that we would continue to be successful." Successes since then, however, have been limited. Many of the trade union leaders in the I940s were radical "freedom fighters" who opposed the undemocratic rulings of the state. The majority of the leaders, although they were "outsiders", included some former cashew workers among them, and some had brothers, wives, mothers, or children who were cashew workers. One also finds the names of a few women on trade-union boards. For long periods, the same trade unions were declared unlawful and the leaders had to go underground, often hiding with cashew families. Even though the organizers of the cashew workers' union came from the outside, the workers did not sense any great distance between 
themselves and the leaders - perhaps a result of the leaders' underground life among the workers.

The earliest trade unions were not affiliated with political parties, although that was soon to be the case. Splits in political parties have subsequently created new trade unions, and since the i950s and I960s, workers in most factories have been divided into three or four different labour organizations, a fact which has led to conflicts of interest and weakened bargaining power. The hierarchy of the trade unions is very strict; and their leaders, without exception, are male politicians. Such trade unions may be accurately characterized as elitist, as they are conspicuously lacking in grass-roots participation.

Dipesh Chakrabarty has argued that the jute workers in early twentiethcentury Bengal failed to organize themselves into successful, democratic trade unions because an old, hierarchical feudal culture was brought into the trade unions. ${ }^{45}$ The early unions in the cashew sector appear not to have been as hindered by the past as those described by Chakrabarty. However, as the politicization and institutionalization of the trade unions progressed, more hierarchical and segregated organizations evolved, and the distance between workers and leaders increased. Workers have been handed down slogans from above, rather than having the power to set their own agenda. The most important issue by far, from the point of view of the leaders, has been nationalizing the cashew factories - an ideological question. However, pressing needs, such as protective gloves to shield women from the corrosive, carcinogenic cashew shell oil, or shelling sticks, or payment for processing saleable broken kernels, were considered too insignificant to fight for by the leadership. These matters, which still have not been addressed - even in the state-owned factories - were the first concerns emerging from the women themselves in the late r930s, with support from the earliest male leaders. It says a great deal about management's attitude toward labour that the practice of not paying workers for processing broken kernels (which are highly saleable in the export market) deprives these women of about twenty per cent of their income! At some point, trade-union leaders even appropriated arguments emanating from the managers, viz. that the women would not carry out their work with due care if they were paid for kernels which break during processing. The women affected have not been able to bring forward these matters, which we may call hidden or forgotten issues. "We can only consider questions which are supported by our leaders", a female tradeunion convenor explained.

In the I970s the Keralite economist, K.P. Kannan, noted that female cashew workers had little or no faith in trade-union leaders. Kannan 
attributed this to the fact that most of the benefits from trade unions had gone to the male workers. ${ }^{46} \mathrm{He}$ implied the existence of a gender conflict between the cashew workers. In interviews, however, female cashew workers indicate that they accept and even support the achievements of male cashew workers. These women consider this natural since, in recent times, lower-caste men are said to be responsible for the maintenance of the family, and are - at least in name - considered the main breadwinners. This is in contradiction to the situation prevailing in earlier days. The concept of the male breadwinner did not exist in the I930s and I940s, when it was taken for granted that low-caste women provided for themselves. It was even stated that lower-caste men may have several wives, because they were not imposing an economic burden upon themselves.

"Male breadwinner" notions emerged beginning with minimum wages in the I950s and have become deeply entrenched among cashew workers ever since. As a result, women have come to accept gendered disparities in pay and a strict gender division of labour. "Why should we object to higher wages for the men? They are our husbands, brothers, fathers, and friends - and besides, they do the heavy work", a female trade-union convenor told me. Conversely, male members of cashew families have often shown their solidarity with women by joining them in the class struggle against factory owners.

The reasons women do not trust trade-union leaders should be attributed to questions of class and alienation from the unions. Trade unions have become new power bases and are totally male-dominated. Their leaders are full-time male politicians. Most of the workers interviewed believed the leaders no longer belonged to the working class. Instances of corruption and collaboration with factory owners are also plausible grounds for popular distrust of the leaders. Caste, however, seems less relevant in accounting for a distance between the leaders and the led. Several low-caste male cashew workers have advanced to careers as trade-union leaders and politicians.

Cashew workers who, together with their families, number more than 500,000 people, have for decades been extremely important voters. They constitute a group which can stage huge demonstrations, manifesting their power on behalf of the political parties to which their unions belong. "They need us to maintain their political power", one of the cashew workers explained. This is not to say that trade unions have grown so totally corrupt they are now useless to the workers, as one scholar in 
Kerala has argued. 47 The same worker just cited, along with many of her co-workers, went on to assert that: "The trade unions have done so much for us!" Such expressions illustrate the power structure of the trade unions, and the lack of grass-roots involvement. The leaders at the top level mainly politicians - have resorted to hunger strikes lasting several days; they have marched many miles and blocked buildings and roads with their bodies; in short they have sacrificed themselves. Still, female workers do not look upon them as part of "their world". Women have clearly been helped by the trade unions, and many rights have been secured for them. However, the dependence of women workers on male leaders is extremely pronounced, and there seems to be no doubt that specific issues related to women's welfare have been neglected.

Jan Breman has concluded that, in spite of little progress, trade unions have played an emancipatory role in India. ${ }^{8}$ To believe that trade unions only function to support the interests of their leaders, or of political parties with which they are affiliated, would be to underestimate the ability of workers to know what is in their own interest. ${ }^{49}$ The Kerala cashew workers' trade unions, with their economic achievements on behalf of the rank and file, validate Breman's point of view, in contrast to Fernandes's argument that women have refrained from becoming members of trade unions due to a consciousness of the exclusionary and gendered practices in them..$^{\circ}$ Trade unions continue to increase their membership among cashew workers due to the fact that, in spite of some negative aspects, workers find the benefits to their advantage - which is not to deny the patriarchal character of those trade unions. ${ }^{5 \mathrm{I}}$ The economic gains are

47. Pillai, "The Economic Impact of Collective Bargaining on Cashew Industry in Kerala". For a discussion of corruption and egoism among trade union leaders, see Jan Breman, "Industrial Labour in Post-Colonial India, I: Industrializing the Economy and Formalizing Labour", International Review of Social History, 44 (1999), pp. 249-300, 292-299. See also K. Mamkoottam, Trade Unionism: Myth and Reality; Unionism in the Tata Iron and Steel Company (New Delhi, 1982), and Fernandes, Producing Workers, p. 81. For a discussion of leadership in Indian trade unions, see Peter Waterman, "Seeing the Straws, Riding the Whirlwind: Reflections on Unions and Popular Movements in India", Journal of Contemporary Asia, I 2 (1982), pp. 464-483. With regard to Kerala, K. T. Rammohan has discussed the growth of a trade-union bourgeoisie in "Kerala CPI(M): All That is Solid Melts into Air", Economic and Political Weekly, 33 (1998), pp. 2579-2582. K.K. George has a more generalizing view of Keralite trade unions, labelling them "managerial barons and marauders of public treasury"; see his "Historical Roots of the Kerala Model and its Present Crisis", Bulletin of Concerned Asian Scholars, 30:4 (1998), pp. 35-40.

48. Breman, "Industrial Labour in Post-Colonial India, I", p. 294.

49. For a similar conclusion, see E.A. Ramaswamy, The Worker and his Union: A Study in South India (Bombay, 1977), p. I89.

50. Fernandes, Producing Workers, p. I5s.

51. For an analysis of patriarchal trade unions in India, see Nivedita Menon, "Women in Trade Unions: A Study of AITUC, INTUC and CITU in the Seventies", in Gothoskar (ed.), Struggles of Women at Work, pp. 186-196. 
especially visible if we contrast the working conditions in Kerala's cashew factories with those in Tamil Nadu, where trade unions are rare. But if we compare wages and living conditions of cashew workers with those of other groups in Kerala, a number of differences are evident.

In the families of the female cashew workers, most of the men are casual workers. In 1998 such individuals typically refused to work below a daily wage of 100 rupees. The daily wage of an agricultural or construction worker might vary between 100 and $\mathrm{I} 50$ rupees. On the other hand, such a labourer might only find one or two days work a week. His wife, meanwhile, works in a registered cashew factory a few months out of the year. Her legal daily wage is about sixty rupees. When the factory closes, she goes to work at an unregistered factory for thirty rupees a day, six days a week.

A paradoxical situation exists between unemployment and the shortage of labour in rural Kerala. In a survey of 24I labour households, about onethird of the agricultural field labourers were willing to work for lower wages, but did not do so because of pressure from the trade unions and fellow workers. ${ }^{2}$ The same kind of pressure was reported by men in the cashew processing families where I conducted interviews. Women, on the other hand, were under such duress that they had to secure food for their children at any price. The husbands in families of cashew workers have come to identify themselves as radical members of the labour movement and assert the right to claim minimum wages. For many of them, however, their class loyalty is dependent upon their wives securing food for the family - often through work in the informal sector. Such as situation is reflected in the following story, related to me in 1998 by a forty-eightyear-old female trade-union convenor named Omana:

I work in a state-owned cashew factory, but now it has been closed for a long time. To survive I have to go to the kudivarappu. You may say that it is to betray the ideology of trade unionism, but you see there is no union in this factory, and the leaders of the unions know about the existence of such factories. In my family it is my two daughters and I who bring the incomes. My husband works mainly in agriculture, but he can only get work now and then. He is not a member of a trade union like I am, but he would never accept work under the legislated minimum wages. Nobody would do that among the men, and nobody would ask them to do it. But I have to. The responsibility for the children has always laid on my shoulders. Men don't hear their cries of hunger. I suppose my husband does his best. I can't change him - and besides, what would people think of him if be started to work for half wages, as I do?

Omana's last sentence clearly demonstrates the impact of gender

52. M.K. Sukumaran Nair, "Labour Shortage in a Labour Surplus Economy? A Study of the Rural Labour Market in Kerala", in Oommen (ed.), Kerala's Development Experience, vol. 2, pp. $247-268,267$. 
ideologies when constructing identities. To some extent women have been defined out of the working class, at least out of the actively politicized working class, by being simply considered dependent housewives. ${ }^{53}$ Among the forty-five workers I interviewed, there was remarkable consensus about a husband's responsibility for maintaining the family and the poor wife's lot to support the family when her husband "failed to get proper payment, but had to refuse to work underpaid", i.e. proclaimed his radicalism. Thus, there is a structural link between men's success in trade-union activities and the ideology of women as merely supplementary providers.

The potential which existed in the I930s and I940s for low-caste women and men to cooperate in a social struggle has been curtailed, not only by the employers' strategy of dismissing men, but also by an increasing gap between the meaning of masculinity and femininity. During a strike in the early I960s, a female cashew worker demonstrated her position as a bona fide worker and an outraged member of a trade union by tearing off her blouse and exposing her breasts to the armed policemen who had come to disperse the crowd. This kind of radical behaviour has long been common among men in Kerala, the confrontation being to accuse the police of cowardice and disloyalty in their attacks on poor, unarmed workers. When a woman did the same, it was so astonishing it caused a long-lived story which was recorded in the trade union's chronicles as an entertaining rarity. What made it unique was not only the fact that she exposed her breasts, but that she had behaved like a man. Such radical behaviour and such a mentality was not expected of a woman. Rather, women were supposed to be timid and in need of male protection. Ironically, thirty years earlier, the same woman would have had no blouse to tear off. The reason would not only have been poverty, but a tradition that did not denounce bare-breasted women as immoral. ${ }^{4}$ Most low-caste women wore only loin-cloths in the I930s and I940s. Moreover, to challenge the police in those days would have been remarkable for any low-caste person, male or female.

Several stories indicate that a gender division of labour has developed in trade union activity. Differences in behaviour between men and women during demonstrations and strikes have emerged over the last few decades, as illustrated below:

The men used to go in the front. Sometimes they climbed the lorries to stop the factory owners from transporting the cashew nuts to clandestine factories and

53. The historian, Joan W. Scott, has strongly argued that the Chartists in nineteenth-century England used a masculine class language which placed "women (and children) in auxiliary and dependent positions"; Scott, Gender and the Politics of History, p. 64.

54. B. Rajeevan, "From Caste to Sex: A Study on Sexuality and the Formation of Modern Subject in Kerala”, in Oommen, Kerala's Development Experience, vol. I, pp. 45-59. 
did other more dangerous things like that. We, the women, did what the comrades instructed us to do. For example, we used to block the gate or just create a crowd.

Indira, born in 1940, a sheller since the mid-1950s, and a trade union convenor at the factory level

In spite of the power of capital, the steady violation of the labour laws in cashew factories, and the poverty of the families concerned, there is one field in which trade unions have been quite successful: the abolition of child labour. This practice has been more or less nonexistent since the late I950s - at least with regard to children below the age of fourteen. If factory owners had had the opportunity to exploit children in Kerala, they would most probably have done so, for this is exactly what the same owners have done and continue to do in cashew factories which they own across the border in the nearby state of Tamil Nadu. A fundamental difference exists, however, in the forces at stake when labour laws are violated in the case of women factory workers. Although the basis of the oppression of women is primarily materialistic, the power which enforces such oppression is the process of social and cultural construction of gender identities, a process which fundamentally reflects a gendered power structure.

\section{THE CONSTRUCTION OF IDENTITIES}

In the early twentieth century, there were diverse gender codes for various castes. It meant something entirely different to be a woman of low caste than to be a high-caste woman who rarely left her house and seldom mixed with men. These differences have since been eroded, so that low-caste women have become part of a general ideology of femininity. Joanna Liddle and Rama Joshi note that the relationship between caste and gender in India was remarked upon by several authors in the 1960s, but none of them offered a theoretical explanation of the correlation. Clearly, the higher the rank a caste was assigned in the social hierarchy, the more regulations it imposed upon women. Prominent among these were the enforcement of child marriage, the prohibition of either divorce or the remarriage of widows, and the institution of purdab (seclusion), all issues controlling women's sexuality. 55 A new loss of freedom by women became conspicuous when a caste tried to rise in the social hierarchy. ${ }^{66}$ Liddle and

55. Joanna Liddle and Rama Joshi, Daughters of Independence: Gender, Caste and Class in India (London, 1986), pp. 57-69.

56. M.N. Srinivas, Caste in Modern India and Other Essays (London, 1962), p. 46; J.H. Hutton, Caste in India: Its Nature, Function and Origins (Bombay, 1963), p. I29, cited in Liddle and Joshi, Daughters of Independence, p. 59. 
Joshi stress the material basis for the relationship between caste and gender: the more property involved, the more important the restriction on women's sexuality. These ideas were very similar to those in Western countries, where women of wealthy families were subjected to stricter control of sexuality than other women. In India, the inability of low-caste men to control their women was part of the circle of behaviour that rendered the whole caste impure. Hence, gender ideology legitimated and reinforced the caste system.

The upward mobility among the low-caste women whom I have interviewed is reflected in the way they have started to cover their bodies, stay home after dark, and cease to mingle with men at liquor- or teashops. The complex relationship between caste and gender needs to be accounted for more comprehensively than on a material basis alone. Hegemonic gender discourses and ideologies are equally decisive in the process of making women more feminine and widening the gap of appropriate behaviour for women and men.

Although it is hardly as pronounced as in years gone by, caste identity is still strong among the workers I have interviewed, and the notions of purity and impurity continue to be of importance. Traditional marriage patterns, in which intercaste liaisons still hardly occur, and the persistence of the caste division of labour, are examples of this. In the factories, the caste division of labour has continued, but differences in wages are only seen along gender lines, showing the primacy of gendered division of labour.

When speaking about identity, the concept of breadwinner is central. Although it is generally taken for granted that husbands are the main breadwinners, a considerable proportion of female cashew workers have held that role. However, these women workers have not been recognized as breadwinners. Because women bear the greatest responsibility for the maintenance of their children, they are compelled by dire necessity to work for any wage, since the absence of work means veritable starvation. This is in spite of the fact that they are considered only supplementary wage earners. "I was the one responsible for the children. Their bellies were crying - so what should I do?" was the explanation a cashew worker gave for her decision to work in a clandestine, unregistered cashew factory. The daily struggle for survival in the midst of poverty unimaginable in the West has left women no choice. The luxury of male members of cashew families demanding minimum wages and rejecting low-paid work (i.e. proudly declaring themselves uncompromizing radical members of the working class) is predicated on women's work and women's assumption of responsibility in providing for their children. A man is expected to show loyalty to his class, even if his family is on the verge of starvation - a view in agonizing conflict with his titular role as provider for the family.

In the I930s and I940s, it was seen as a matter of course among the lower 


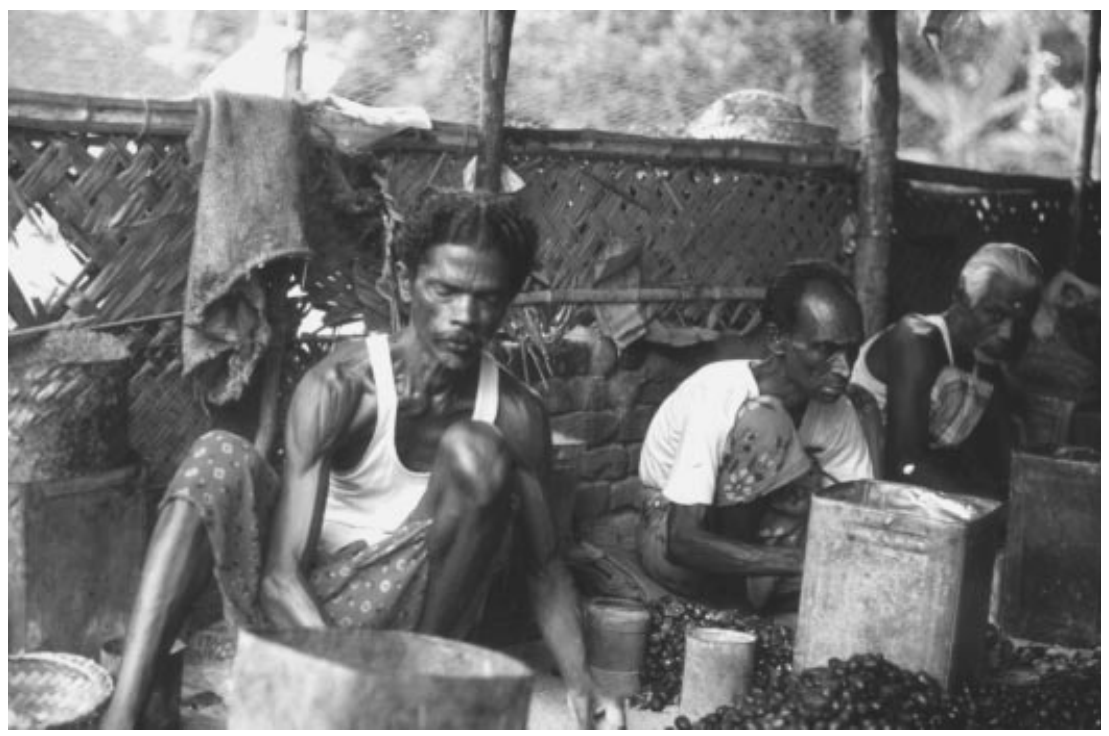

Figure 4. Male shellers of the Kurava caste (formerly "Untouchables"). Today, male shellers are rarely encountered, but in the I940s it was a common sight to find low-caste men and women shelling side by side. In the decades that followed, the few men remaining in this section were classified as "not able-bodied".

Copyright photograph Anna Lindberg

castes that all family members worked and contributed to the household. People saw their own poverty at first in terms of caste affiliation, then, as the labour movement grew stronger, also in terms of class exploitation. Although we may speak about an emerging class consciousness, the fact remains that a central politicized class identity never obtained a firm hold on female workers. They believe that they belong to the working class, and their identity as such is politicized because they are engaged in collective class actions. However, their activities have not been empowering to them; rather than lead, they have been led. These women seem to be have been quite cognizant of the capitalist forces behind their exploitation, and aware of the necessity of the trade-union struggle; nevertheless, impoverished female cashew workers have begun to explain their poverty as a consequence of marriage. Lalitha, a woman of the Pulaya caste, born in 1972, a cashew worker since 1990, married in I990, says: "I am poor because my husband doesn't take the responsibility that he should. A husband should provide for the family, but in my case it is the other way around.” The explanations of poverty that are commonly heard begin to have a familiar ring: "My husband is dead (or sick, alcoholic, disabled, unwilling, unemployed, or has disappeared) and can't provide for me." "My parents chose the wrong husband for me." "I have just had bad luck in my 
Table I. Various attributes related to gender

\begin{tabular}{|c|c|}
\hline Femininity & Masculinity \\
\hline \multicolumn{2}{|c|}{ 1. Bodily attributes (work-related) } \\
\hline Weakness & Strength \\
\hline Dexterity & Awkwardness \\
\hline Untechnical & Technically-minded \\
\hline \multicolumn{2}{|c|}{ 2. Mental attributes (connected to relations) } \\
\hline Patient & Impatient \\
\hline Docile & Unruly \\
\hline Loyal & Rebellious/Faithless \\
\hline Home-oriented & Outgoing \\
\hline Timid & Fearless \\
\hline \multicolumn{2}{|c|}{ 3. Resultant attributes (connected to way of living) } \\
\hline Dependent & Supportive (breadwinner) \\
\hline Helpless & Protecting \\
\hline Nurturing/Emotional & Political/Rational \\
\hline
\end{tabular}

marriage." At the individual level such women have started to identify themselves as "anomalies". This can be considered the result of their constructing gender identity through a perception of femininity and masculinity which they have imbibed in the factories, the trade unions, and in society at large. The construction of femininity and masculinity is also the construction of a difference that creates meaning for a specific behaviour and gives people their identities. ${ }^{57}$ The following behavioural dichotomies appear related to gender. (Table I).

The ideology of femininity and masculinity among low-caste women and men was not as dichotomized in the I930s and I940s as it became later. In earlier times, women, like men, could carry out hard work, go out at night, provide for themselves, and dress only in a loincloth. In a corresponding way, some low-caste men did not assert their masculinity and were content to perform softer "female" work tasks. All this was also an expression of one's material circumstances, and there was no space for being "feminine" or "masculine".

In narratives of the past, we must always be aware of the tendency to idealize the "good old days". In point of fact, however, my informants made disparaging references to bygone times as a period when, according to them, men were less masculine and women less feminine, leading them presented at the Nordic Feminist Thought Conference, University of Trondheim, 22 May 1996. 
to speak of it as a "shameful past". Significantly, this shameful past was not a topic they brought forward by themselves. Stories about militant female trade-union activists of the older generation were recounted, but such women were not seen by most of my informants as heroines to emulate. Rather, they were ridiculed as backward, masculine women.

With a more rigid gender division of labour, the introduction of male breadwinner wages, and the emergence of a male power base in the trade unions, the gender ideology described above became more pronounced among cashew workers. For poor women, the improvement of material conditions, however slight, acted as an incentive to nourish their dream of the right to be feminine.

The dependency of women upon men manifested itself during the I970s in an emerging system of dowry payments made to the bridegroom at marriage - something which had not previously existed among the lower castes in Kerala. Since then, it has become a strategy for parents, and often single mothers, to try and arrange marriages for their daughters so as to secure a "good" husband, i.e. one who can provide for a wife and keep her away from factory work, so that hopefully she may have a better life than her mother.

Equity accumulated by women in their capacity as workers, including pensions and bonuses, or real estate distributed to them through land reforms, has come to be transferred to men at marriage, as illustrated below:

When my daughter was going to marry, it was difficult. Our relatives brought a proposal, and it seemed as if that man was educated and had a job. He demanded so much dowry and I told him that I will give land worth 25,000 rupees, 6,000 rupees in cash, and five sovereigns of gold. This was in 1992. To get the money, I resigned from the cashew nut factory and I got a nice sum as a pension, 2,000 rupees. The rest I borrowed. Now I work in another factory, but I am not a registered worker.

Sarasamma, woman of the Pulaya caste, born 1950, sheller since 1965

Sarasamma retired prematurely at the age of forty-three in order to obtain her legal pension as a lump sum "to rescue her daughter". Her strategy forced her to leave a registered factory and enter a situation in which she had no legal rights and few opportunities for securing her old age.

The dowry system is very much a part of the gender ideology which defines women as dependent. It reflects a belief in a "happy nuclear family" centred around a male breadwinner, something which seems unshakeably rooted in the minds of cashew workers. Trade unions, while ostensibly condemning dowry payments, have supported and encouraged them by establishing funds for poor workers to be used for their daughters' marriages - something which has further strengthened the view that the dowry system is "natural". 
The majority of female cashew workers, especially the "middle generation" that has worked for ten to thirty years, assert that in spite of all their poverty and misery, working in the cashew factory has given them the ability to survive, the possibility of feeding their children, and some power in the household. "I want to continue the work in the cashew factory. It gives me security, since I don't trust my husband's willingness or capacity to maintain the family - but I want my daughters to be housewives." This seems to be the general opinion, and may be viewed as a common strategy for giving the next generation of women an opportunity to escape from immediate capitalist exploitation.

Several scholars have questioned the link between empowerment and wage labour for Third-World women. ${ }^{58}$ My findings point towards a correlation between women's earnings from wage labour and their power in the household. This is not to subscribe to Engels's view that women's incorporation into wage labour will dissolve gender discrimination. However, the little power these women have achieved in the household, they are prepared to exchange for a better material life for their daughters; they are well aware that a "woman's wage" is not enough to feed a family. A woman has to work up to five times longer than a man to achieve the same income, a fact that motivates every effort to avoid such a situation and ignites the hope of having a "normal" nuclear family.

Individuals always have several overlapping identities. The different generations of women interviewed have shown a shift in their dominant identification from caste and class to that of gender.

\section{CONCLUSION}

Cashew workers live in a state of tension between their daily experiences and the gender ideology which makes them consider their situation as paradoxical or even anomalous. Most female cashew workers have witnessed their mothers working in the cashew factories, and most of them have also seen their mothers contributing substantially to the income of the household. Their experiences as workers and central family breadwinners did not result in "working-class" becoming their dominant identity. They have developed a politicized class identity, but a peripheral one. The concept of experience, so central for Thompson, can be expanded to include other experiences that have proven more important in the shaping of their identities. The experience of being a "temporary guest" in the labour movement, the steady victim of labour law violations and unemployment, of being defined as the Other, feeling alienated from the 
trade unions, and being thoroughly dependent on men - on an ideological and a discursive level - have exerted the strongest influences on their identities. The language of class has been dominant and has obscured patriarchal structures. These women would never explain their poor working conditions as a matter of "bad luck", as they did with their bad husbands, but rather attribute it to the capitalist system.

The scope of action for cashew workers has been reduced by the power of capital, by the poverty which has forced them to accept any wage they can get, and by the expenditure of energy which their unending struggle for survival has necessitated, ${ }^{59}$ but hegemonic gender ideology has further acted to limit their space. Gender ideologies are realized in practice, and not restricted to ideas or discourses.

The women studied here have gone through a process which may be termed effeminization, by which is meant representing women with the kinds of epithets relating to femininity alluded to earlier, and the consequences of this, which include stereotyping them as housewives. Maria Mies introduced the term housewifization, meaning "a process in which women are socially defined as housewives, dependent for their sustenance on the income of a husband, irrespective of whether they are de facto housewives or not" ${ }^{6}$ Effeminization includes the process Mies terms housewifization, but has a broader meaning, as it encompasses perceptions of a woman's way of dressing, behaving, and acting in different spaces - such as in the factory, in union participation, in the household, and out in society at large. The processes through which such ideologies become dominant, and shift from one generation to another, are deeply imbedded in hegemonic discourses, and to a lesser extent mediated through socialization from mothers to daughters. Diana Mulinari has shown that poor mothers in Nicaragua socialize their daughters not to depend on men for their own or their children's maintenance. Radical, revolutionary women have served as models for young women. ${ }^{6 \mathrm{I}}$ The cashew workers of Kerala show a contrasting pattern, indicating the importance of forces outside the experiences of individuals. However, the concerns of these impoverished women, giving high priority to making good marriages for their daughters by earnestly seeking reliable "breadwinners" for them, must not be taken as a lack of consciousness of the

59. James Scott, in a study of peasants in Malaysia, stressed poverty, physical coercion, and power relations, and thereby rejected hegemonic ideologies or "false consciousness", as the real hindrance for radical actions. See James C. Scott, Weapons of The Weak: Everyday Forms of Peasant Resistance (New Haven, CT, 1985).

6o. Maria Mies, The Lace Makers of Narsapur: Indian Housewives Produce for the World Market (London, I982), p. I80.

6r. Diana Mulinari, Motherwork and Politics in Revolutionary Nicaragua (Lund, 1995), pp. II 8 - I 20. 
oppressive patriarchal structure under which they live. It is, rather, a survival strategy and the acknowledgement of enormous structural hindrances. ${ }^{62}$ In it we see an attempt to plan for their children's future in a rational way within a limited space of which they are well aware.

The case of the Kerala cashew workers illustrates an instance of bold and brutal capitalist exploitation, manifested in the factory owners' ploys to shift factories to other states, open up clandestine factories, and constantly flaunt labour laws. It also highlights the way in which production and reproduction, social struggle, ideologies, and the cultural and social construction of gender identities are closely related. Explaining women's exploitation by the power of capitalism, the limitations imposed on them by poverty, or their lack of class-consciousness, is insufficient. As we have seen, state-owned factories have also discriminated against women, in spite of a pronounced labour-friendly policy. In the course of promoting class and caste emancipation, the radical forces behind the Kerala Model have neglected the question of gender. Caste identities have changed from being politicized to being more of a passive identity, only activated on certain occasions, whereas gender identities have never have been politicized at all.

To the extent that a woman's exploitation in the workplace has been condoned, while a man's has not, the unfortunate result has often been that labouring women have failed to be identified as true workers and true radical members of the labour movement - not only by society at large, but by themselves as well.

Hegemonic gender ideologies, when applied to the cashew workers of Kerala, contrast their experiences. By perpetrating gender stereotypes in which active, politicized workers are automatically equated with male identities (the same males who often must ask their wives for money), while the multiple role of nurturer, caregiver, and supporter of the family remains inextricably linked with the female (although these same women are driven by necessity to become actual breadwinners), such discourses confound gender identities among men and women.

62. For a view of absence of resistance as a recognition of structural constraints, see Pierre Bourdieu, "The Social Space and the Genesis of Groups", Theory and Society, I4 (1985), pp. 723-744. 